\title{
Antibacterial Activity of Some Lactic Acid Bacteria Isolated from an Algerian Dairy Product
}

\author{
Abdelkader Mezaini, ${ }^{1,2}$ Nour-Eddine Chihib, ${ }^{2}$ Abdelkader Dilmi Bouras, ${ }^{1}$ \\ Naima Nedjar-Arroume, ${ }^{2}$ and Jean Pierre Hornez ${ }^{2}$ \\ ${ }^{1}$ Laboratoire de Bio-Ressources Naturelles Locales, Université Hassiba Ben Bouali de Chlef, 02000 Chlef, Algeria \\ ${ }^{2}$ Laboratoire de Procédés Biologiques, Génie Enzymatique et Microbien (ProBioGEM) IUT A/Polytech'Lille, \\ Université de Lille 1-Sciences et Technologies, Avenue Langevin, 59655 Villeneuve d'Ascq Cedex, France
}

Correspondence should be addressed to Abdelkader Mezaini, abmezaini@yahoo.fr

Received 23 December 2008; Revised 14 May 2009; Accepted 15 June 2009

Recommended by Benny C. Zee

In the present study, the antibacterial effect of 20 lactic acid bacteria isolates from a traditional cheese was investigated. 6 isolates showed antibacterial effect against Gram positive bacteria. Streptococcus thermophilus T2 strain showed the wide inhibitory spectrum against the Gram positive bacteria. Growth and bacteriocin production profiles showed that the maximal bacteriocin production, by $S$. thermophilus $\mathrm{T} 2$ cells, was measured by the end of the late-log phase $\left(90 \mathrm{AU} \mathrm{ml}^{-1}\right)$ with a bacteriocine production rate of $9.3\left(\mathrm{AU} \mathrm{ml} \mathrm{m}^{-1}\right) \mathrm{h}^{-1}$. In addition, our findings showed that the bacteriocin, produced by $S$. thermophilus $\mathrm{T} 2$, was stable over a wide $\mathrm{pH}$ range (4-8); this indicates that such bacteriocin may be useful in acidic as well as nonacidic food. This preliminarily work shows the potential application of autochthonous lactic acid bacteria to improve safety of traditional fermented food.

Copyright (C) 2009 Abdelkader Mezaini et al. This is an open access article distributed under the Creative Commons Attribution License, which permits unrestricted use, distribution, and reproduction in any medium, provided the original work is properly cited.

\section{Introduction}

Lactic Acid Bacteria (LAB) isolated from dairy products have received increased attention as a potential food preservative due to their antagonistic activity against many food born pathogen such as Listeria monocytogenes [1]. LAB are widely distributed in the nature, they are typically involved in a large number of the spontaneous food fermentation, and they have been extensively studied [2]. Some members of $\mathrm{LAB}$ produce bacteriocins and bacteriocins-like substances which may inhibit growth of spoilage and pathogenic microorganisms [3]. Bacteriocins from LAB are bioactive peptides or proteins with antimicrobial activity toward Gram positive bacteria, including closely related strains and/or spoilage and pathogenic bacteria [4]. Bacteriocins are ribosomaly synthesized and extracellulary released bioactive peptides or peptide complexes which have bactericidal or bacteriostatic effect [5]. Use of either the bacteriocins or the bacteriocin-producing LAB like starter cultures for food preservation has received a special attention [6]. Moreover, bacteriocins are innocuous due to proteolytic degradation in the gastrointestinal tract $[7,8]$. S. thermophilus is a lactic acid bacterium of major importance in food industry like the manufacture of yoghourt [9]. Some of S. thermophilus strains produce a bacteriocin named thermophilin which is active against several LAB and food spoilage bacteria such as Clostridium sporogenes. In view of its technological and biochemical properties the above bacteriocin can be considered as a potential bioprerservative [10]. Some of other LAB like Enterococcus, Lactococcus, and Pediococcus are also widely used as natural preservatives, due to the potential production of metabolites with antimicrobial activity such as organic acids, hydrogen peroxide, antimicrobial enzymes and bacteriocins [11].

The aim of the present study is to assess antimicrobial activity of some lactic acid bacteria strains isolated from traditional fermented dairy products prepared from raw milk, Raib, which is obtained after spontaneous curdling of raw milk within 24 to 36 hours at ambient temperature. In addition, preliminary investigations on a bacteriocin produced by $S$. thermophilus strain isolated in this work will be presented. 


\section{Materials and Methods}

2.1. Isolation of Lactic Acid Bacteria. The bacterial strains used in this study were isolated from fermented traditional milk, Raib, manufactured without starter cultures. Samples were collected all over Chlef regions and obtained with collaboration of Bioressources research laboratory. LAB were isolated from Raib, by homogenizing $10 \mathrm{~g}$ samples of cheese in $90 \mathrm{~mL}$ saline solution and then plating suitable serial dilutions onto different media: BHI, MRS, and M17 (Biokar Diagnostics, Beauvais, France). The plates were incubated aerobically at $30^{\circ} \mathrm{C}$ for 48 hours, and then several colonies were picked at random for identification. Cell morphology and Gram-staining reaction were examined by light microscopy, and the catalase activity was carried out. Phenotypic identification was based upon physiological and biochemical characteristics; sugar fermentation profile, in the API-20 Strep CH and API-50 CH fermentation, was carried out according to the manufacturer's instructions (bioMe'rieux, Marcy l'Etoile, France).

2.2. Detection of Antibacterial Activity. For detection of antagonistic activity, an agar spot test was used. The agar spot test was a modification of that described by Tomé et al. [12]. Overnight cultures, on MRS medium, of the strains to be tested for production of antimicrobial compound were centrifuged ( 10 minutes at $15000 \mathrm{~g}, 4^{\circ} \mathrm{C}$ ). Cell-free supernatants were filtered across cellulose acetate filter $(0.2 \mu \mathrm{m})$ to remove residual cells.

An overnight culture $\left(37^{\circ} \mathrm{C}\right)$ of the target strain was diluted in sterile Mueller-Hinton Medium, and $2 \mathrm{~mL}$ of $\mathrm{ca} \cdot 10^{6} \mathrm{CFU} \mathrm{mL} \mathrm{m}^{-1}$ were spread on solid Mueller-Hinton medium. After 5 minutes of contact, the excess was removed and the Petri dishes were dried for 10 minutes. Samples $(10 \mu \mathrm{L})$ of filtered cell-free supernatants were spotted on the agar plate. The target strains used in this study are Bacillus cereus CIP 6624, Bacillus subtilis ATCC 6633, Escherichia coli CIP 35218, Enterococcus faecalis CIP 29212, Listeria innocua ATCC 51742, Salmonella typhimurium CIP 5858, Staphylococcus aureus CIP 29213, and Staphylococcus epidermitidis ATCC 14990.

2.3. Sensitivity of Bacteriocin to Enzymes, $\mathrm{pH}$ and Heat Treatment. The biochemical nature of the antibacterial agent was studied on both chloroform extract and cell-free supernatant; all the samples were incubated for 1 hour at $37^{\circ} \mathrm{C}$ before the antilisterial essay. The $\mathrm{pH}$ of cell-free supernatants was adjusted to 6.5 with $\mathrm{NaOH}(1 \mathrm{~N})$ and then treated with catalase (Sigma; $\left.500 \mathrm{IU} \mathrm{mL}^{-1}\right)$. The cell-free supernatant was also submitted to heat treatment $\left(60-95^{\circ} \mathrm{C}\right)$ and to several $\mathrm{pH}$ (4-8). The chloroform extract was treated with $\alpha$-amylase (Sigma; $1 \mathrm{mg} \mathrm{mL}^{-1} 100 \mathrm{mM}$ phosphate buffer, $\mathrm{pH}$ 6.9), $\alpha$-chymotrypsin (Sigma, $1 \mathrm{mg} \mathrm{mL}^{-1}, 0.05 \mathrm{M}$ Tris$\mathrm{HCl}$ buffer ( $\mathrm{pH}$ 8.0)-0.01 M $\mathrm{CaCl}_{2}$ ), Pronase E (Sigma; $1 \mathrm{mg} \mathrm{mL}^{-1}$ in $100 \mathrm{mM}$ Tris-HCl buffer, $\mathrm{pH} 3$ ), Proteinase $\mathrm{K}$ (Sigma; $1 \mathrm{mg} \mathrm{mL}^{-1}$ in $100 \mathrm{mM}$ Tris- $\mathrm{HCl}$ buffer, $\mathrm{pH} 7.5$ ), and Trypsin (Sigma, $1 \mathrm{mg} \mathrm{mL}^{-1} 50 \mathrm{mM}$ Tris-HCl buffer $\mathrm{pH}$ 8.0). Prior to being assayed for bacteriocin activity, preparations containing pronase $\mathrm{E}$ were adjusted to $\mathrm{pH}$ 6.0. Neutralized cell-free supernatant neutralized cell-free supernatant treated with catalase, heat-treated supernatant, and chloroform extract were spotted against L. innocua. The enzymes were heat inactivated for 3 minutes at $100^{\circ} \mathrm{C}$. For each test, untreated bacteriocin plus buffer, bacteriocin plus buffer treated 5 minutes at $100^{\circ} \mathrm{C}$, buffer alone and enzymes solutions served as controls $[13,14]$.

2.4. Growth Kinetic and Bacteriocin Production. Growth experiments were performed in ErlenMeyer flask of $500 \mathrm{~mL}$ containing $250 \mathrm{~mL}$ of MRS broth ( $\mathrm{pH} \mathrm{6.5)}$ at $37^{\circ} \mathrm{C}$ without shaking. An overnight pre-culture of $S$. thermophilus was used for the inoculation of the MRS broth at initial cell den-

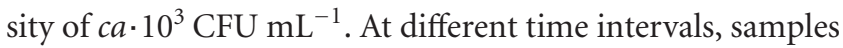
were removed from the culture and used for optical density measurement $(660 \mathrm{~nm})$, viable and cultivable count (CFU $\left.\mathrm{mL}^{-1}\right)$, extracellular $\mathrm{pH}$ measurements, and bacteriocin production. The antibacterial concentration of each sample was conducted with the critical method of dilutions [15]. The bacteriocin concentration Arbitrary Unit $\mathrm{mL}^{-1}\left(\mathrm{AU} \mathrm{mL} \mathrm{m}^{-1}\right)$ was calculated as the inverse of the strongest dilution which induces the inhibition of L. innocua. All experiments were repeated at least three times. The experiments were repeated three times, and results are expressed as mean \pm standard error to the mean.

2.5. Bacteriocin Extraction. The extraction was realized from cell-free culture supernatant of $S$. thermophilus obtained after centrifugation of overnight culture (20 minutes at $15000 \mathrm{~g}$ at $4^{\circ} \mathrm{C}$ ). The extraction was performed according to Burianek and Yousef [16]. The culture supernatant $(100 \mathrm{~mL})$ was stirred vigorously for 20 minutes with chloroform (v/v) and transfer in separation funnel, the interface layer between the aqueous and organic phases, which contain bacteriocin, was harvested, and the residual chloroform was eliminated by speed vacuum (50 hours, Unique, Martinsried, Germany). Then bacteriocin activity was measured in the interface layer, aqueous and organic phases.

2.6. Plasmid Extraction. The plasmid extraction was performed from a cell pellet of an overnight culture of $S$. thermophilus $(250 \mathrm{~mL})$ using Miniprep Spin kit together with the corresponding buffers purchased from QIAGEN (Hilden, Germany). S. thermophilus plasmidic DNA analysis was performed by electrophoresis (1 hour, $100 \mathrm{~V}$ ) using a $0.7 \%$ agarose gel dissolved in Tris $45 \mathrm{mM}$; Borate $45 \mathrm{mM}$; EDTA $1 \mathrm{mM}$; pH 8. The electrophoresis gels were analyzed under UV using Molecular Imager Gel Doc System (Bio-Rad, Hercules, USA).

\subsection{HPLC Purification of Supernatant Chloroform Extract.} The conditions for bacteriocin isolation were realized, through analytical RP-HPLC, on the chloroform extract. The liquid chromatographic system consisted of a Waters $600 \mathrm{E}$ automated gradient controller pump module, a Waters Wisp 717 automatic sampling device, and a Waters 996 photodiode array detector. Spectral and chromatographic data were 
TABLE 1: Lactic acid bacteria isolated from traditional dairy product (Raib).

\begin{tabular}{lcc}
\hline Strain & Source & Growth medium \\
\hline Lactococcus lactis S1 & Raib & MRS \\
Lactococcus lactis S2 & Raib & MRS \\
Lactococcus lactis S3 & Raib & MRS \\
Lactococcus lactis S4 & Raib & MRS \\
Lactococcus lactis S5 & Raib & MRS \\
Lactococcus lactis S6 & Raib & MRS \\
Lactococcus lactis S7 & Raib & MRS \\
Lactococcus lactis S8 & Raib & MRS \\
Lactococcus lactis S9 & Raib & MRS \\
Lactococcus lactis S10 & Raib & MRS \\
Lactococcus lactis S11 & Raib & MRS \\
Lactococcus lactis S12 & Raib & MRS \\
Lactococcus lactis S13 & Raib & MRS \\
S. thermophilus T1 & Raib & MRS \\
S. thermophilus T2 & Raib & MRS \\
S. cremoris R1 & Raib & MRS \\
S. cremoris R2 & Raib & MRS \\
S. cremoris R3 & Raib & MRS \\
Lactococcus diacetylactis V1 & Raib & MRS \\
Lactococcus diacetylactis V2 & Raib & MRS \\
\hline
\end{tabular}

stored on a NEC image 466 computer. Millennium software was used to plot, acquire, and analyze chromatographic data.

All of the chromatographic processes were performed on an Uptisphere $\mathrm{C}_{18}$ column $(150 \mathrm{~mm} \times 4.6 \mathrm{~mm}$, UP5ODB615QS, Interchim, Montluçon, France). The mobile phase was water/trifluoroacetic acid (1000: 1, v/v) as eluent $\mathrm{A}$ and acetonitrile/trifluoroacetic acid (1000:1, $\mathrm{v} / \mathrm{v}$ ) as eluent B. The flow rate was $1 \mathrm{~mL} / \mathrm{min}^{-1}$. Samples were filtered through $0.22 \mu \mathrm{m}$ filters and then injected. The gradient applied was $0-50 \%(\mathrm{v} / \mathrm{v}) \mathrm{B}$ over 100 minutes then $50 \%-100 \%(\mathrm{v} / \mathrm{v}) \mathrm{B}$ over 5 minutes and 15 minutes at $100 \%(\mathrm{v} / \mathrm{v}) \mathrm{B}$. Online UV absorbance scans were performed between 200 and $300 \mathrm{~nm}$ at a rate of one spectrum per second with a resolution of $1.2 \mathrm{~nm}$. Chromatographic analyses were completed with Millennium software [17].

\section{Results}

3.1. Antimicrobial Activity. Twenty LAB strains, isolated from Algerian dairy milk (Table 1), were screened for their antagonistic activity against Listeria innocua, Enterococcus faecalis, Bacillus cereus, Bacillus subtilis, Staphylococcus aureus, Staphylococcus epidermitidis, Escherichia coli, and Salmonella typhimurium. The results of Table 2 show that six isolates were active against one or more tested strains. However, $S$. thermophilus T2 strain showed a wide inhibitory spectrum against all the Gram positive target bacteria used in this study except against Staphylococcus aureus (Table 2). In addition, $S$. thermophilus T2 did not show any inhibitory activity against Gram negative bacteria used in this study: Escherichia coliandSalmonella typhimurium.

3.2. Nature of the Inhibitory Agent. Our results showed that the free-cell supernatant remained active, against sensitive target strains, even when the $\mathrm{pH}$ was adjusted to $\mathrm{pH} 7$. However, when the cell-free supernatant and the chloroform extract were exposed to the proteolytic enzymes (Table 3 ) no inhibitory activity was observed against Listeria innocua by contrast to the control tests which showed an inhibitory activity against the target strain (Table 3 ). In addition, when the cell-free supernatant and the chloroform extract were exposed to the action of $\alpha$-amylase and catalase similar inhibitory activity was measured when compared with the control test against L. innocua. These results suggest that the biochemical nature of the molecule produced by $S$. thermophilus is peptidic. Moreover, the antimicrobial activity appeared to be heat resistant. Thus, the inhibitory activity of the chloroform extract was still measured after a heat treatment of 30 minutes at $90^{\circ} \mathrm{C}$. Our results showed also that in a range of $\mathrm{pH} 4-8$ similar antibacterial activities of the chloroform extract were obtained against L. innocua.

3.3. Extraction of the Bacteriocin Produced by S. thermophilus. The extraction of the bacteriocin produced by $S$. thermophilus T2 strain from culture supernatant was realized with chloroform, a water-immiscible solvent. The method used concentrates the bacteriocin at the interface between chloroform and the aqueous culture of the producing bacterium. We demonstrated that no bacteriocin activity was detected in the solvent phase (data not shown). In addition, the precipitate at the interface between the chloroform and culture supernatant fluid contained most of the bacteriocin activity in the mixture. The precipitate at the interface was harvested, and the residual chloroform was eliminated by speed vacuum. After HPLC reversed-phase chromatography, bacteriocin activity was associated with two peaks eluting at 17 minutes and 110 minutes (Figure 3). These results showed that the antibacterial activity of $S$. thermophilus T2 could be associated with two molecules which present different hydrophobicity.

3.4. Growth Kinetics and Bacteriocin Biosynthesis. Growth and bacteriocin production of $S$. thermophilus was studied in MRS broth at $37^{\circ} \mathrm{C}$ at $\mathrm{pH}$ 6.5. Under these conditions bacteriocin activity was detected at 4 hours of incubation at the beginning of the exponential phase, at a cell concentration of $c a \cdot 10^{4} \mathrm{CFU} \mathrm{\textrm {mL } ^ { - 1 }}\left(12 \mathrm{AU} \mathrm{mL} \mathrm{mL}^{-1}\right)$. The results of Figure 1 showed that bacteriocin production increases with the increase of cell concentration to reach a maximum of $90 \mathrm{AU} \mathrm{mL}^{-1}$ with a bacteriocin production rate of $9.3\left(\mathrm{AU} \mathrm{mL} \mathrm{m}^{-1}\right) \mathrm{h}^{-1}$. This concentration was reached between 12 and 14 hours of incubation at $37^{\circ} \mathrm{C}$. During the stationary phase both bacteriocin concentration and the cell concentration remained at a steady state (Figure 1). Antibacterial activity decreased after 24 hours of incubation after having reached maximum levels after 14 hours of incubation (data not shown). 
TABLE 2: Antibacterial spectrum of the cell-free supernatant of the six lactic acid bacteria isolated from the traditional dairy product (Raib).

\begin{tabular}{lc}
\hline Strain & Strains inhibited \\
\hline Lactococcus lactis $\mathrm{S} 1$ & Listeria innocua, Enterococcus faecalis \\
Lactococcus lactis $\mathrm{S} 2$ & Listeria innocua \\
Lactococcus lactis $\mathrm{S} 7$ & Listeria innocua, Enterococcus faecalis Bacillus cereus \\
Lactococcus lactis $\mathrm{S} 9$ & Listeria innocua, Bacillus cereus \\
S. thermophilus $\mathrm{T} 2$ & Bacillus cereus, Bacillus subtilis, Listeria innocua, Enterococcus faecalis, and Staphylococcus epidermitidis \\
S. cremoris $\mathrm{R} 3$ & Enterococcus faecalis, Bacillus cereus \\
Lactococcus diacetylactis $\mathrm{V} 1$ & Enterococcusfaecalis \\
\hline
\end{tabular}

TABLE 3: Effect of different treatments on cell-free supernatant and chloroform extract of $S$. thermophilus T2. Relative activity was measured by an agar diffusion test against Listeria innocua. ( - ): no inhibition; (+): slight inhibition; $(++)$ : moderate inhibition; $(+++)$ : strong inhibition.

\begin{tabular}{lc}
\hline Treatments & Relative activity \\
\hline Enzymatic treatments & - \\
\hline Proteinase K & - \\
Pronase E & - \\
$\alpha$-chymotrypsin & - \\
Trypsin & ++ \\
$\alpha$-amylase & ++ \\
Catalase & +++ \\
Control & \\
\hline pH treatments & +++ \\
\hline 4 & +++ \\
5 & +++ \\
6 & +++ \\
7 & +++ \\
8 & +++ \\
Control & \\
\hline Heat treatments & +++ \\
\hline $60^{\circ} \mathrm{C}$ & +++ \\
$70^{\circ} \mathrm{C}$ & ++ \\
$80^{\circ} \mathrm{C}$ & ++ \\
$90^{\circ} \mathrm{C}$ & ++ \\
$95^{\circ} \mathrm{C}$ & + \\
Control & + \\
\hline
\end{tabular}

3.5. Plasmid Content. The genes encoding for bacteriocin are either chromosomic or plasmidic [18, 19]. The aim for this preliminary investigation is to assess the presence of plasmid in S. thermophilus cells. The analysis of the plasmidic DNA extraction showed that $S$. thermophilus seems to have a single plasmid as shown in Figure 2. In addition, DraI fragmentation pattern of the plasmid resulted in three restriction fragments with approximately $2.2 \mathrm{~kb}, 1.5 \mathrm{~kb}$, and $0.5 \mathrm{~kb}$. Thus the size of the plasmid could be of at least $4.2 \mathrm{~kb}$. This preliminary result is of importance since in many lactic acid bacteria bacteriocins and carbohydrate fermentation exopolysaccharide production and antiphage mechanisms are carried by the same plasmid as reported previously by Martinez-Bueno et al. [20] and Turgeon and Moineau [21].

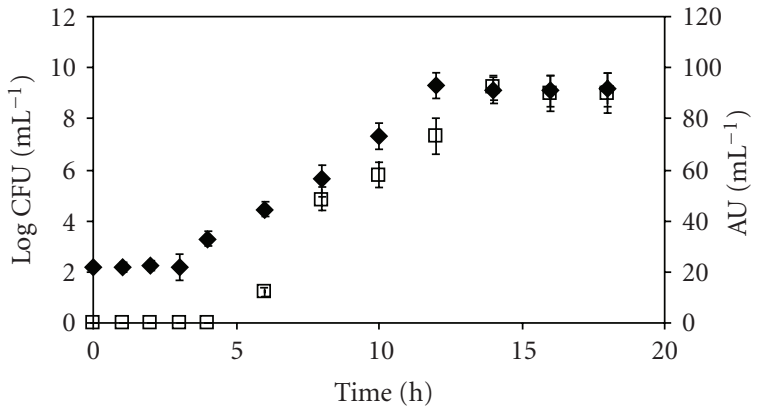

Figure 1: Growth kinetic and bacteriocin production by $S$. thermophilus. The growth was performed at an initial $\mathrm{pH}$ of 6.5 , at $37^{\circ} \mathrm{C}$ without shaking. (\$) growth kinetic. ( $\square$ ) bacteriocin production. The experiments were repeated three times and results represent the mean \pm standard error to the mean.

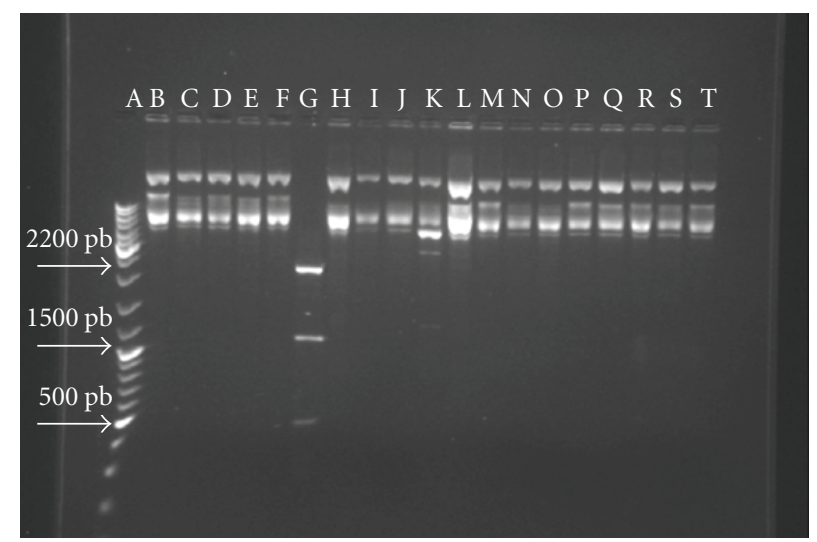

FIGURE 2: Agarose gel electrophoresis of plasmid from S.thermophilus digested by various restriction endonucleases: (A) O'Gene Ruler control (B); AvaIII (C); BamHI ; (D) BglII ; (E) BstEII; (F) EcoRI; (G) DraI; (H) EcoRV; (I) HindIII; (J) NdeI; (K) MfeI; (L) PstI; (M) PvuII; (N) SacI; (O) ScaI; (P) SphI; (Q) XhoI; (R) AatII; (S) AhaIII; (T) NcoI.

\section{Discussion}

Bacteriocins from lactic acid bacteria are of importance in bioconservation of various foods. Moreover, the use of more than one $\mathrm{LAB}$ bacteriocin as a combination of biopreservative may have major applications in improving food safety [1]. In the present study, the inhibitory effect of the cell-free filtrates of each of the 20 isolates was evaluated. 


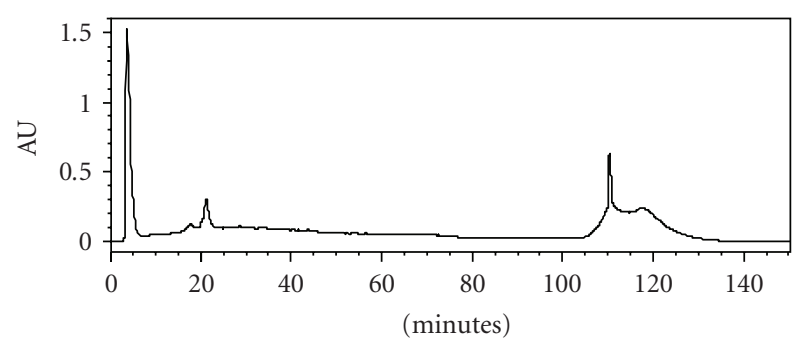

Figure 3: Elution pattern of chloroform extract from $S$. thermophilus T2 strain by reversed-phase high-performance liquid chromatography.

Antimicrobial activity was observed for 6 isolates, and only against Gram positive bacteria. The biochemical nature of the antibacterial molecule produced by $S$. thermophilus T2 was studied in both the cell-free supernatant and the chloroform extract. Our results showed that the molecule, produced by $S$. thermophilus, is peptidic since the antibacterial activity of the molecule was lost after digestion with proteolytic enzymes. However, the neutralization ( $\mathrm{pH} 7)$ and addition of catalase or $\alpha$-amylase to the cell-free supernatant did not result in the loss of the antilisterial activity. Our results showed also that the bacteriocin produced by $S$. thermophilus is heat stable (up to 30 minutes at $95^{\circ} \mathrm{C}$ ); these results are similar to what has been reported for thoenicin [22]. In addition, the bacteriocin was stable over a wide $\mathrm{pH}$ range, this indicates that such bacteriocin may be useful in acidic as well as nonacidic food; similar $\mathrm{pH}$ stability results have been reported for propionicin PLG1 [14]. Growth and bacteriocin production profiles showed that the maximal bacteriocin production was measured by the end of the latelog phase. The level of production remained at a steady state during the stationary phase; similar results were obtained by Ivanova et al. [23]. However, bacteriocin production decreases after 24 hours of incubation after having reached maximum levels after 14 hours. This reduction could be a result of the inactivation of bacteriocin by extracellular proteases.

Preliminary characterization of the bacteriocin produced by $S$. thermophilus T2 was realized in the present study. It was found that the bacteriocin inhibits closely related Gram positive strains like Listeria innocua and Enterococcus faecalis. Activity against Gram negative was rarely reported for bacteriocin $[24,25]$. Active substance from culture supernatant of $S$. thermophilus $\mathrm{T} 2$ was obtained according to the procedure described by Burianek and Yousef [16]. Chloroform was added to the cell-free supernatant in a separator funnel, the bacteriocin was concentrated at the interface between chloroform and the aqueous phase. This method effectively recovers higher bacteriocin yield and results in relatively clean preparations. Recovery of bacteriocin by the chloroform extraction was 10-fold higher when compared with ammonium sulphate precipitation (data not shown). The chloroform extraction procedure saves time, and it is easy to perform. This study allowed to underline the presence of at least one plasmid, of $4.2 \mathrm{~kb}$ as reported for many strains of S. thermophilus [21].
In conclusion, the study of autochthonous LAB will help to select the best candidates for improving the microbiological safety of traditional food products such as Raib and may increase their shelf life. Such a collection could be used for construction of specific starter cultures for fermented food products.

\section{Acknowledgment}

This work was supported by a Ph.D. fellowship, within the PNE (Plan National Exceptionnel) Program administered by the Conférence Régionale, Ministère de l'Enseignement Supérieur et de la Recherche Scientifique (Algeria). The authors sincerely thank Professor D. Guillochon, ProBioGEM laboratory.

\section{References}

[1] M. Jamuna and K. Jeevaratnam, "Isolation and partial characterization of bacteriocins from Pediococcus species," Applied Microbiology and Biotechnology, vol. 65, no. 4, pp. 433-439, 2004.

[2] W. H. Holzapfel, R. Geisen, and U. Schillinger, "Biological preservation of foods with reference to protective cultures, bacteriocins and food-grade enzymes," International Journal of Food Microbiology, vol. 24, no. 3, pp. 343-362, 1995.

[3] T. R. Klaenhammer, "Bacteriocins of lactic acid bacteria," Biochimie, vol. 70, no. 3, pp. 337-349, 1988.

[4] J. R. Tagg, A. S. Dajani, and L. W. Wannamaker, "Bacteriocins of gram positive bacteria," Bacteriological Reviews, vol. 40, no. 3, pp. 722-756, 1976.

[5] S. Garneau, N. I. Martin, and J. C. Vederas, "Two-peptide bacteriocins produced by lactic acid bacteria," Biochimie, vol. 84, no. 5-6, pp. 577-592, 2002.

[6] C. Sabia, G. Manicardi, P. Messi, S. De Niederhäusern, and M. Bondi, "Enterocin 416K1, an antilisterial bacteriocin produced by Enterococcus casseliflavus IM 416K1 isolated from Italian sausages," International Journal of Food Microbiology, vol. 75, no. 1-2, pp. 163-170, 2002.

[7] L. M. Cintas, J. M. Rodriguez, M. F. Fernandez, et al., "Isolation and characterization of pediocin L50, a new bacteriocin from Pediococcus acidilactici with a broad inhibitory spectrum," Applied and Environmental Microbiology, vol. 61, no. 7, pp. 2643-2648, 1995.

[8] L. De Vuyst and E. J. Vandamme, "Nisin, a lantibiotic produced by Lactococcus lactis subsp. Lactis: properties, biosynthesis, fermentation and application," in Bacteriocins of Lactic Acid Bacteria, L. De Vuyst and E. J. Vandamme, Eds., pp. 151-221, Balackis Academic and Professional, Glasgow, UK, 1994.

[9] U. Purwandari, N. P. Shah, and T. Vasiljevic, "Effects of exopolysaccharide-producing strains of Streptococcus thermophilus on technological and rheological properties of settype yoghurt," International Dairy Journal, vol. 17, no. 11, pp. 1344-1352, 2007.

[10] A. Aktypis, M. Tychowski, G. Kalantzopoulos, and G. Aggelis, "Studies on bacteriocin (thermophilin T) production by Streptococcus thermophilus ACA-DC 0040 in batch and fedbatch fermentation modes," Antonie van Leeuwenhoek, vol. 92, no. 2, pp. 207-220, 2007. 
[11] M. Mataragas, E. H. Drosinos, and J. Metaxopoulos, "Antagonistic activity of lactic acid bacteria against Listeria monocytogenes in sliced cooked cured pork shoulder stored under vacuum or modified atmosphere at $4 \pm 2{ }^{\circ} \mathrm{C}$," Food Microbiology, vol. 20, no. 2, pp. 259-265, 2003.

[12] E. Tomé, P. Teixeira, and P. A. Gibbs, "Anti-listerial inhibitory lactic acid bacteria isolated from commercial cold smoked salmon," Food Microbiology, vol. 23, no. 4, pp. 399-405, 2006.

[13] A. Cherif, W. Rezgui, N. Raddadi, D. Daffonchio, and A. Boudabous, "Characterization and partial purification of entomocin 110, a newly identified bacteriocin from Bacillus thuringiensis subsp. Entomocidus HD110," Microbiological Research, vol. 163, no. 6, pp. 684-692, 2008.

[14] W. J. Lyon and B. A. Glatz, "Partial purification and characterization of a bacteriocin produced by Propionibacterium thoenii," Applied and Environmental Microbiology, vol. 57, no. 3, pp. 701-706, 1991.

[15] A. Mayr-Harting, A. J. Herdgs, and R. C. W. Berkeley, "Methods for styding bacteriocins," Methods in Microbiology, vol. 7, pp. 315-422, 1972.

[16] L. L. Burianek and A. E. Yousef, "Solvent extraction of bacteriocins from liquid cultures," Letters in Applied Microbiology, vol. 31, no. 3, pp. 193-197, 2000.

[17] Q. Zhao, P. Molina, and J. M. Piot, "Peptic peptide mapping by HPLC, on line with photodiode array detection, of a hemoglobin hydrolysate produced at pilot-plant scale from an ultrafiltration process," Journal of Liquid Chromatography and Related Technologies, vol. 20, no. 11, pp. 1717-1739, 1997.

[18] E. Balla, L. M. T. Dicks, M. Du Toit, M. J. Van Der Merwe, and W. H. Holzapfel, "Characterization and cloning of the genes encoding enterocin 1071A and enterocin 1071B, two antimicrobial peptides produced by Enterococcus faecalis BFE 1071," Applied and Environmental Microbiology, vol. 66, no. 4, pp. 1298-1304, 2000.

[19] H. Abriouel, E. Valdivia, M. Martinez-Boueno, M. Maqueda, and A. Galvez, "A simple method for semi-preparative-scale production and recovery of enterocin AS-48 derived from Enterococcus faecalis subsp. liquefaciens A-48-32," Journal of Microbiological Methods, vol. 55, no. 3, pp. 599-605, 2003.

[20] M. Martinez-Bueno, A. Galvez, E. Valdivia, and M. Maqueda, "A transferable plasmid associated with AS-48 production in Enterococcus faecalis," Journal of Bacteriology, vol. 172, no. 5, pp. 2817-2818, 1990.

[21] N. Turgeon and S. Moineau, "Isolation and characterization of a Streptococcus thermophilus plasmid closely related to the pMV158 family," Plasmid, vol. 45, no. 3, pp. 171-183, 2001.

[22] I. R. Van Der Merwe, R. Bauer, T. J. Britz, and L. M. T. Dicks, "Characterization of thoeniicin 447, a bacteriocin isolated from Propionibacterium thoenii strain 447," International Journal of Food Microbiology, vol. 92, no. 2, pp. 153-160, 2004.

[23] I. Ivanova, V. Miteva, T. Stefanova, et al., "Characterization of a bacteriocin produced by Streptococcus thermophilus 81," International Journal of Food Microbiology, vol. 42, no. 3, pp. 147-158, 1998.

[24] N.-E. Chihib, L. Monnerat, J. M. Membré, and J.-L. Tholozan, "Nisin, temperature and $\mathrm{pH}$ effects on growth and viability of Pectinatus frisingensis, a gram-negative, strictly anaerobic beer-spoilage bacterium," Journal of Applied Microbiology, vol. 87, no. 3, pp. 438-446, 1999.

[25] G. M. Vignolo, F. Suriani, A. P. de Ruiz Holgado, and G. Oliver, "Antibacterial activity of Lactobacillus strains isolated from dry fermented sausages," Journal of Applied Bacteriology, vol. 75, no. 4, pp. 344-349, 1993. 


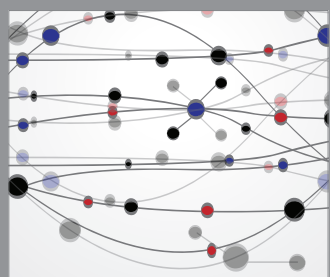

The Scientific World Journal
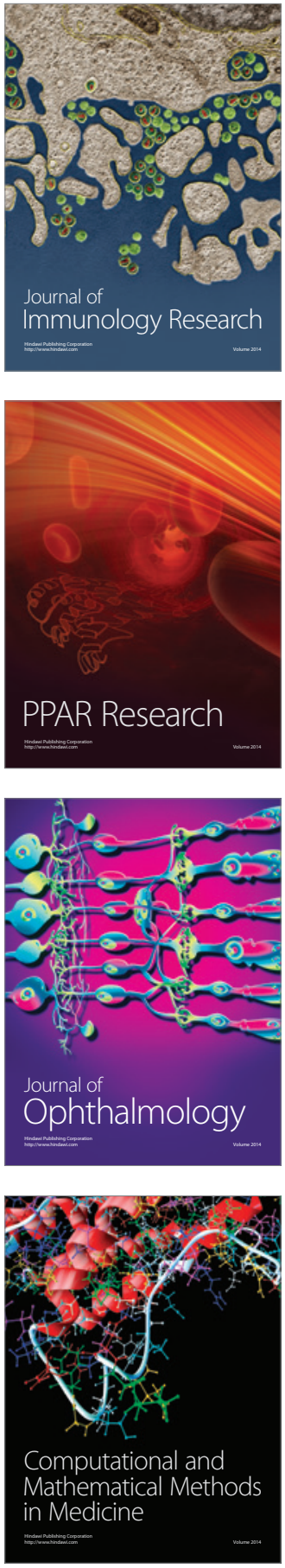

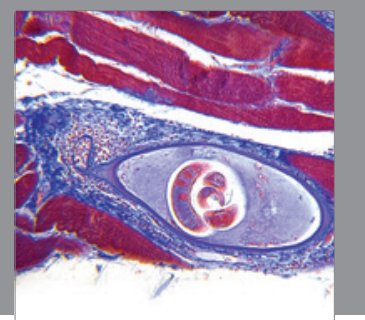

Gastroenterology

Research and Practice
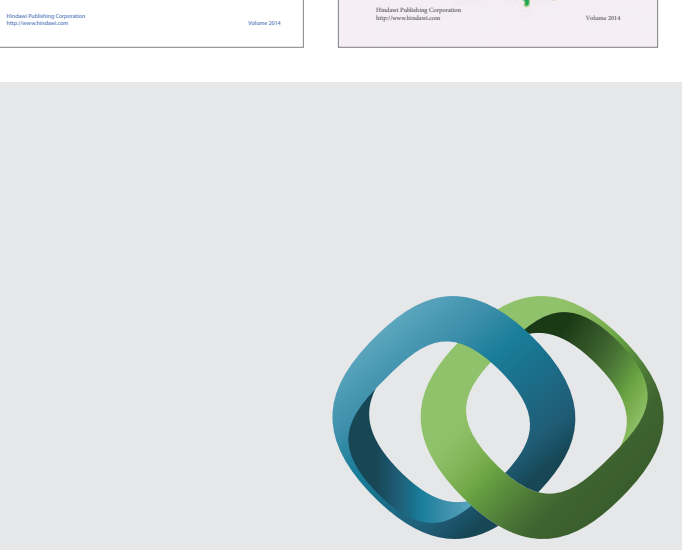

\section{Hindawi}

Submit your manuscripts at

http://www.hindawi.com
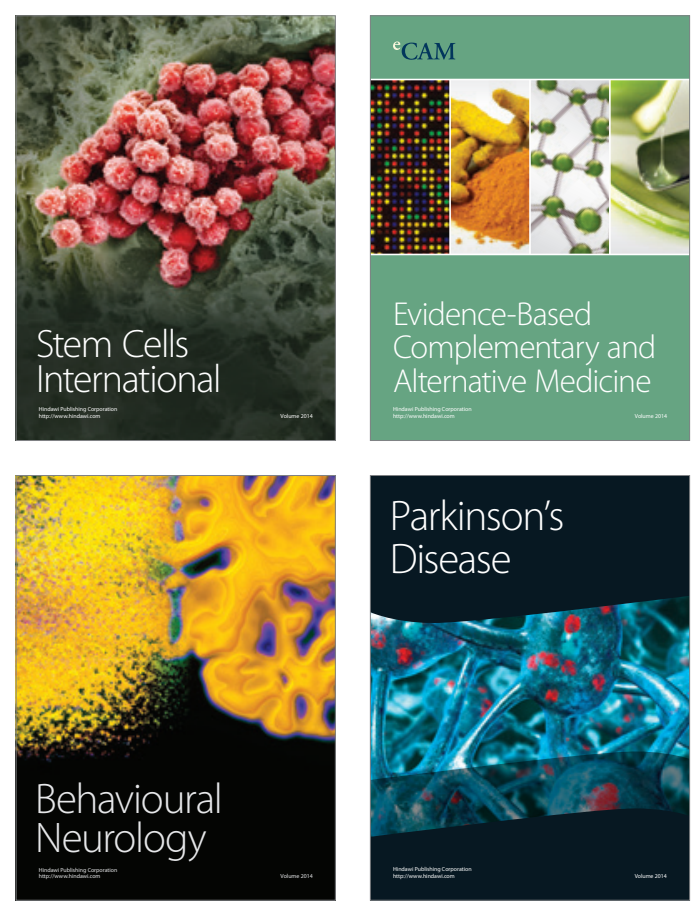

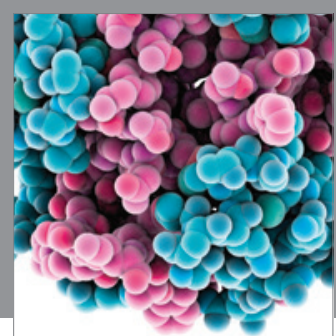

Journal of
Diabetes Research

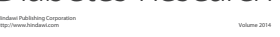

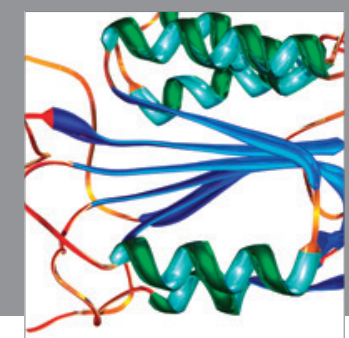

Disease Markers
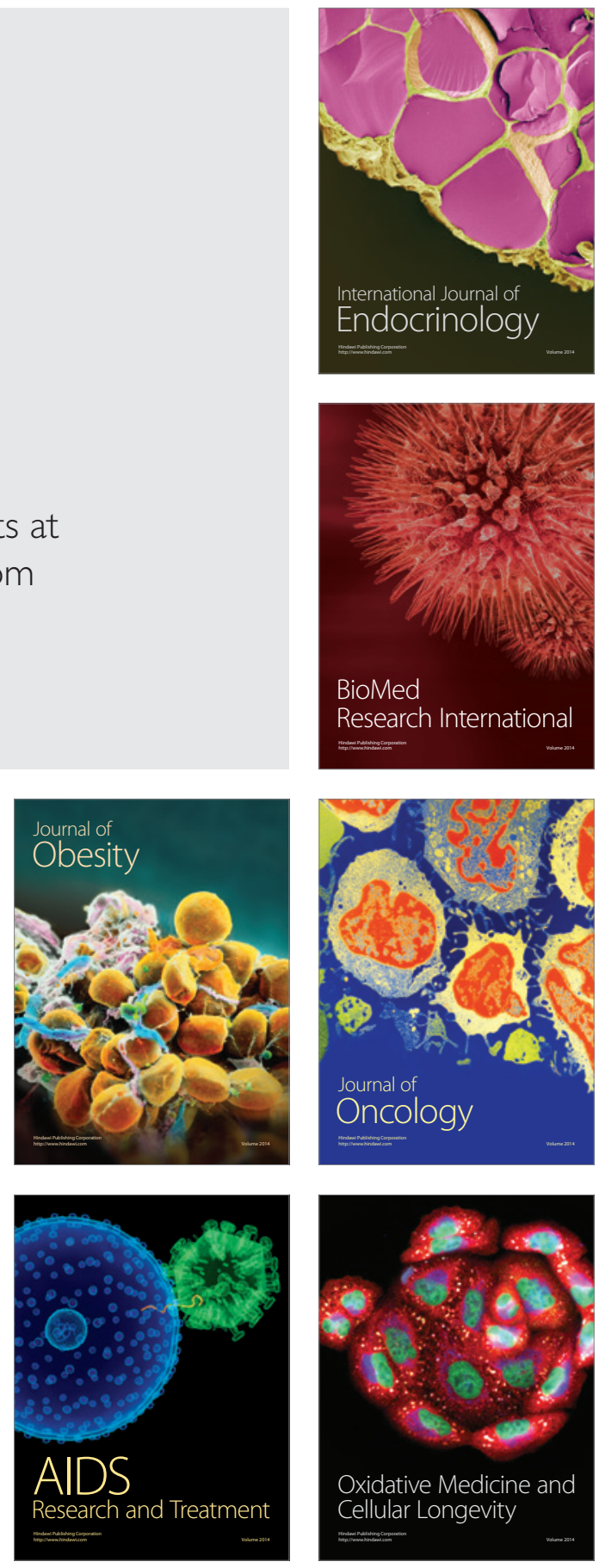